\title{
Endothelial expression of c-kit and CD68 in dental follicles of human impacted third molars
}

\author{
M.C. Rusu, A. Rașcu, M.D. Stoenescu \\ Division of Anatomy, Faculty of Dental Medicine, "Carol Davila" University of Medicine and Pharmacy, Bucharest, Romania
}

[Received: 18 July 2017; Accepted: 10 November 2017]

Background: Periodontal tissue remnants of odontogenesis constitute the dental follicle (DF) which is actually considered a stem niche in adults. However, potentialities of local endothelia within this niche seem overlooked. We thus aimed at testing the endothelial cells expression of c-kit, the progenitor cells marker, and CD68, commonly regarded as a monocyte/macrophage marker, in human DFs. Materials and methods: We performed an immunohistochemical study using these two markers which were applied on samples collected from ten adult patients. Results: The markers were positively expressed in endothelial cells, as well as in spindle-shaped stromal cells of the DF.

Conclusions: The origin of DF stem or progenitor cells needs reviewing in the light of these findings, as endothelium could be a donor site for niche inhabitants. (Folia Morphol 2018; 77, 3: 485-488)

Key words: stem niche, dental stem cells, monocytes, CD117, immunohistochemistry

\section{INTRODUCTION}

Odontogenesis occurs inside the dental follicle (or sac) (DF) which could be characterised as the remnant of tissues that participate in the odontogenesis and surround an impacted crown [25]. Various dental stem niches were characterised [16], including the DF niche which corresponds to dental follicle progenitor cells (DFPCs) $[16,18]$. Such DFPCs are multipotent mesenchymal stem cell-like cells and can be isolated during the extraction of molar teeth $[5,8]$. Thus, they have potential for multilineage differentiation and self-renewal capacity. A hypothesis has been recently proposed that a subset of dental stem/progenitor cells belong to the endothelial lineage and exhibit a spindle-shaped fibroblastoid morphology, similar to telocytes [16]. Telocytes are fibroblastoid cells with long, thin and moniliform prolongations, termed so in 2010 by Popescu and Faussone-Pellegrini [19]. However, similar cells were found in perivascular lo- cations by Majno [14] in 1965 and were indicated as "veil cells", as previously discussed [17, 21]. The hypothesis of endothelial-derived dental stem/progenitor cells is in accordance with previous evidence of dental fibroblastoid and perivascular cells capable of differentiation into odontoblasts [6] and with evidence of endothelial-specific Weibel-Palade bodies in pericytes as well as in pericytes-deriving immediate perivascular transitional cells within the dental pulp niche [2]. On the other hand, it has been reported [16] that also monocyte-deriving progenitors have spindleshaped morphologies and exhibit mixed features of endothelial cells, monocytes and mesenchymal cells [24]. We therefore hypothesised that endothelial cells of the DF equally exhibit a progenitor and myeloid phenotype. We aimed at evaluating by an in situ study on human samples the expressions of CD117/c-kit, the stem/progenitor marker, and CD68, the myeloid marker in endothelia of the DF. 


\section{MATERIALS AND METHODS}

Human DFs were collected after obtaining written informed consent from 10 patients (14-19 years of age) undergoing third impacted molars extraction for orthodontic or therapeutic reasons at the "Dr. Carol Davila" University Emergency Military Central Hospital, Bucharest, Romania. All experiments on human subjects were conducted in accordance with the Declaration of Helsinki (http://www.wma.net/ en/30publications/10policies/b3/index).

Tissue samples were fixed for $24 \mathrm{~h}$ in buffered formalin (8\%) and were processed with an automatic histoprocessor (Diapath, Martinengo, BG, Italy) with paraffin embedding. Sections were cut manually at $3 \mu \mathrm{m}$ and mounted on SuperFrost ${ }^{\circledR}$ electrostatic slides for immunohistochemistry (Thermo Scientific, MenzelGläser, Braunschweig, Germany). Histological evaluations used $3 \mu \mathrm{m}$ thick sections stained with haematoxylin and eosin. Internal negative controls resulted when the primary antibodies were not applied on slides.

We used primary antibodies for CD117/c-kit (clone Y145, Biocare Medical, Concord, CA, USA, 1:100) and CD68 (clone KP1, Biocare Medical, Concord, CA, USA, 1:100).

For immunolabelling, tissues were deparaffinised and rehydrated, then endogenous peroxidase was blocked using Peroxidased 1 (Biocare Medical, Concord, CA, USA). For the heat induced epitope retrieval was used the Decloaking Chamber (Biocare Medical, Concord, CA, USA) and retrieval solution $\mathrm{pH} 6$ (Biocare Medical, Concord, CA, USA), the latter being a buffer specially formulated for superior $\mathrm{pH}$ stability at high temperatures. Background blocker (Biocare Medical, Concord, CA, USA) was used to reduce non-specific background staining. The primary antibody was then applied. As detection system was used, for the CD68 antibody, MACH 4 (Biocare Medical, Concord, CA, USA), a two-step (probe/polymer) universal HRP detection method. For the CD117/c-kit antibody was used as detection system MACH 2 rabbit HRP polymer detection (Biocare Medical, Concord, CA, USA) which consists of a single reagent applied after the primary antibody. Then a HRP-compatible chromogen (DAB) was applied. Sections were counterstained with haematoxylin and rinsed with deionised water. For washing steps was used TBS solution, $\mathrm{pH}$ 7.6.

\section{RESULTS}

Epithelial and connective (stromal) components were accurately identified on slides. There was no histological evidence of an inflammatory status of the tis-

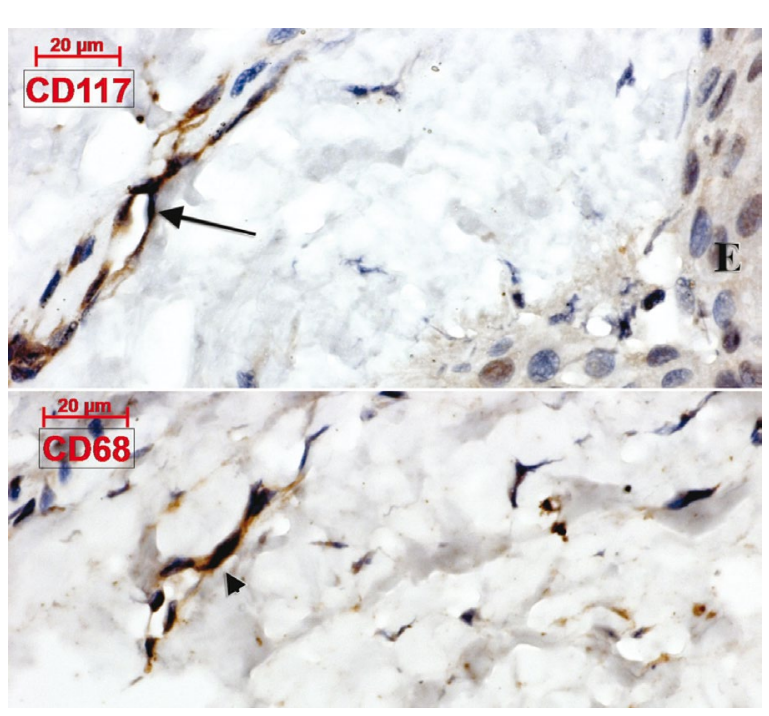

Figure 1. Human adult dental follicle microvessels express CD117/ /c-kit (arrow) and CD68 (arrowhead); E — follicle epithelium.

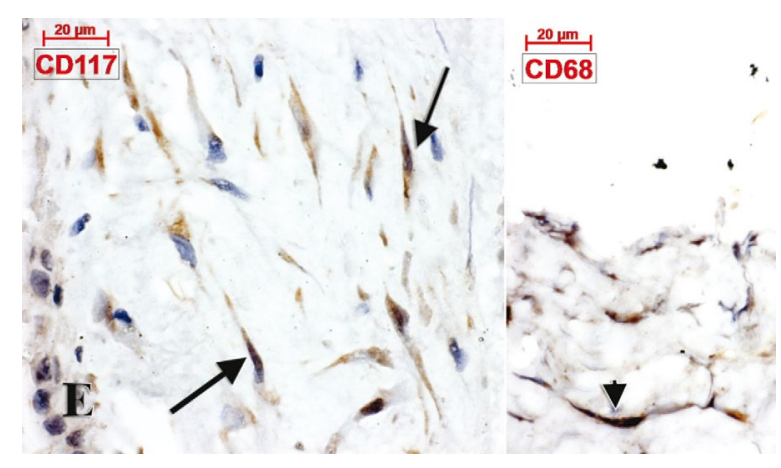

Figure 2. Human adult dental follicle spindle-shaped stromal cells positively express CD117/c-kit (arrows) and CD68 (arrowhead); E - follicle epithelium.

sues labelled for immunohistochemistry. Endothelial cells of microvessels assumed being postcapillary venules were found equally expressing CD117/c-kit and CD68 (Fig. 1). Expression of the two markers was also found in fibroblastoid stromal cells of the DF (Fig. 2). Epithelia of the DF were negative for CD117/c-kit and for CD68. Nevertheless, isolated stromal cells, mostly small-sized, were found expressing CD68.

\section{DISCUSSION}

Different studies of DF progenitor cells found that these cells express CD29, CD44, CD73, CD90, CD105 and nestin but do not express CD14, CD31, CD34, CD45 and CD117 [22]. In these regards, the stem niche players of the DF were not related to a haematopoietic (CD34, CD45, CD117), or to an endothelial 
(CD31, CD34), or to a myeloid (CD14) phenotype. However, in human midterm foetuses were found CD117/c-kit-expressing spindle-shaped cells of the DF which were building a network coating the outer adamantine epithelium [3]. In these regards, the stromal expression of c-kit in DF stromal cells should be regarded as constitutive.

A study of inflammatory cells subsets, such as antibodies-recognising macrophages identified by their expression of $C D 68$, around partly erupted third molars, found that DFs did not contain increased number of inflammatory cells [12]. Thus, it can be reasonably speculated that the CD68-positive phenotype we found was not related to inflammation, and the CD68- and CD117/c-kit-expressing fibroblastoid stromal cells are rather related to a myeloid and progenitor phenotype. Such phenotype should indicate endothelial progenitor cells. This is because haemangioblasts can leave the bone marrow for nonhaematopoietic tissues. Such cells, or their progeny, could be a source of endothelial cells in adult; these endothelial progenitors can be identified by the positive expressions of CD117/c-kit, as well as CD68 [23].

Interestingly, positive expressions of CD117/c-kit and CD68 were also found in endothelial cells of the DFs postcapillary venules. The endothelial expression of CD68, of variable intensity, was previously detected in cells of the myeloid lineage as wells as in fibroblasts and endothelial cells, feeding the assumption that CD68 is not a selective macrophage marker but rather a lysosomal protein that is enriched in macrophages [7]. This was further supported by evidence of CD68 expression in mesenchymal stromal/stem cells [11]. On the other hand, normal human endothelial cells, such as those of the umbilical vein, of normal lymph nodes and of the bone marrow, are known to produce stem cell factor (SCF, the c-kit ligand) and to possess highaffinity c-kit receptors [1]. Therefore, it appears that in situ vascular endothelial cells, as well as stromal cells, of the DF share haematopoietic and myeloid antigens. On one hand, this could indicate that residents of the DF stroma are involved in neovessel formation, but on the other hand, it may suggest that endothelial cells can play a role in the maintenance of a local haematopoietic stem niche. It was shown that haematopoietic stem cells (HSCs) reside in perivascular niches in adult [4] and, in embryo, the endothelium has the potential of HSC emergence [27]. This is supported by experiments that found the aortic endothelium being haemogenic, the HSCs emerging from it into the sub-aortic space by a new type of cell behaviour termed endothelial-haematopoietic transition [10]. On the other hand, most of circulating endothelial cells in peripheral blood originate from vessel walls [13]; thus, such cells could populate different tissues, including the tissue they originate from.

\section{CONCLUSIONS}

The origin of DF stem/progenitor cells also needs reviewing in the light of these findings, as endothelium could be a donor site of niche inhabitants. This is strengthened by the positive expression of Stro-1 in DF cells $[9,26]$ because, although Stro- 1 is regarded as a mesenchymal stem cell marker [20], it is intrinsically a $75 \mathrm{kD}$ endothelial antigen [15]. This is also supported by recent findings in the dental pulp stem niche that indicate that pericytes and transitional cells partly embedded within the microvascular walls contain Weibel-Palade bodies [2], which are exclusively indicating an endothelial phenotype.

\section{REFERENCES}

1. Broudy VC, Kovach NL, Bennett LG, et al. Human umbilical vein endothelial cells display high-affinity c-kit receptors and produce a soluble form of the c-kit receptor. Blood. 1994; 83(8): 2145-2152, indexed in Pubmed: 7512842.

2. Carlile MJ, Sturrock MG, Chisholm DM, et al. The presence of pericytes and transitional cells in the vasculature of the human dental pulp: an ultrastructural study. Histochem J. 2000; 32(4): 239-245, indexed in Pubmed: 10872889.

3. Didilescu AC, Pop F, Rusu MC. c-kit positive cells and networks in tooth germs of human midterm fetuses. Ann Anat. 2013; 195(6): 581-585, doi: 10.1016/j. aanat.2013.06.002, indexed in Pubmed: 23932767.

4. Ding L, Saunders TL, Enikolopov G, et al. Endothelial and perivascular cells maintain haematopoietic stem cells. Nature. 2012; 481(7382): 457-462, doi: 10.1038/nature10783, indexed in Pubmed: 22281595.

5. Dziubińska P, Jaskólska M, Przyborowska P, et al. Stem cells in dentistry: review of literature. Pol J Vet Sci. 2013; 16(1): 135-140, indexed in Pubmed: 23691589.

6. Fitzgerald M, Chiego DJ, Heys DR. Autoradiographic analysis of odontoblast replacement following pulp exposure in primate teeth. Arch Oral Biol. 1990; 35(9): 707-715, indexed in Pubmed: 2091590.

7. Gottfried E, Kunz-Schughart LA, Weber A, et al. Expression of CD68 in non-myeloid cell types. Scand J Immunol. 2008; 67(5): 453-463, doi: 10.1111/j.1365-3083.2008.02091.x, indexed in Pubmed: 18405323.

8. Huang GTJ, Gronthos S, Shi S. Mesenchymal stem cells derived from dental tissues vs. those from other sources: their biology and role in regenerative medicine. J Dent Res. 2009; 88(9): 792-806, doi: 10.1177/0022034509340867, indexed in Pubmed: 19767575. 
9. Kémoun $P$, Laurencin-Dalicieux $S$, Rue J, et al. Localization of STRO-1, BMP-2/-3/-7, BMP receptors and phosphorylated Smad-1 during the formation of mouse periodontium. Tissue Cell. 2007; 39(4): 257-266, doi: 10.1016/j. tice.2007.06.001, indexed in Pubmed: 17662325.

10. Kissa K, Herbomel P. Blood stem cells emerge from aortic endothelium by a novel type of cell transition. Nature. 2010; 464(7285): 112-115, doi: 10.1038/nature08761, indexed in Pubmed: 20154732.

11. La Rocca G, Anzalone R, Farina F. The expression of CD68 in human umbilical cord mesenchymal stem cells: new evidences of presence in non-myeloid cell types. Scand J Immunol. 2009; 70(2): 161-162, doi: 10.1111/j. 1365-3083.2009.02283.x, indexed in Pubmed: 19630923.

12. Laine $M$, Ventä I, Hyrkäs $T$, et al. Chronic inflammation around painless partially erupted third molars. Oral Surg Oral Med Oral Pathol Oral Radiol Endod. 2003; 95(3): 277-282, doi: 10.1067/moe.2003.86, indexed in Pubmed: 12627097.

13. Lin Y, Weisdorf DJ, Solovey A, et al. Origins of circulating endothelial cells and endothelial outgrowth from blood. J Clin Invest. 2000; 105(1): 71-77, doi: 10.1172/JCl8071, indexed in Pubmed: 10619863.

14. Majno G. Ultrastructure of the vascular membrane. Handbook of physiology. 1965; 3: 2293-2375.

15. Ning $H$, Lin $G$, Lue TF, et al. Mesenchymal stem cell marker Stro-1 is a 75 kd endothelial antigen. Biochem Biophys Res Commun. 2011; 413(2): 353-357, doi: 10.1016/j. bbrc.2011.08.104, indexed in Pubmed: 21903091.

16. Perlea P, Rusu MC, Didilescu AC, et al. Phenotype heterogeneity in dental pulp stem niches. Rom J Morphol Embryol. 2016; 57(4): 1187-1193, indexed in Pubmed: 28174783.

17. Petre N, Rusu MC, Pop F, et al. Telocytes of the mammary gland stroma. Folia Morphol. 2016; 75(2): 224-231, doi: 10.5603/FM.a2015.0123, indexed in Pubmed: 26711648.
18. Petrovic V, Stefanovic V. Dental tissue--new source for stem cells. Scientific World J. 2009; 9: 1167-1177, doi: 10.1100/ tsw.2009.125, indexed in Pubmed: 19838602.

19. Popescu LM, Faussone-Pellegrini MS. Telocytes - a case of serendipity: the winding way from Interstitial Cells of Cajal (ICC), via Interstitial Cajal-Like Cells (ICLC) to telocytes. J Cell Mol Med. 2010; 14(4): 729-740, doi: 10.1111/j.15824934.2010.01059.x, indexed in Pubmed: 20367664.

20. Rusu MC, Hostiuc S, Dermengiu D, et al. STRO-1 positive pulmonary valve stem cells: preliminary report. Rom J Leg Med. 2015; 23(1): 1-4, doi: 10.4323/rjlm.2015.1.

21. Rusu MC, Hostiuc S, Vrapciu AD, et al. Subsets of telocytes: myocardial telocytes. Ann Anat. 2017; 209: 37-44, doi: 10.1016/j. aanat.2016.09.006, indexed in Pubmed: 27777113.

22. Saito MT, Silvério KG, Casati MZ, et al. Tooth-derived stem cells: Update and perspectives. World J Stem Cells. 2015; 7(2): 399-407, doi: 10.4252/wjsc.v7.i2.399, indexed in Pubmed: 25815123.

23. Schatteman GC, Awad O. Hemangioblasts, angioblasts, and adult endothelial cell progenitors. Anat Rec A Discov Mol Cell Evol Biol. 2004; 276(1): 13-21, doi: 10.1002/ ar.a.10131, indexed in Pubmed: 14699630.

24. Seta N, Kuwana M. Human circulating monocytes as multipotential progenitors. Keio J Med. 2007; 56(2): 41-47, indexed in Pubmed: 17609587.

25. Tambuwala AA, Oswal RG, Desale RS, et al. An evaluation of pathologic changes in the follicle of impacted mandibular third molars. J Int Oral Health. 2015; 7(4): 58-62, indexed in Pubmed: 25954073.

26. Zhang C, Cheng Xr. [Isolation and characterization of dental follicle cells from adult human dental follicle tissues]. Zhonghua Kou Qiang Yi Xue Za Zhi. 2013; 48(2): 96-101, indexed in Pubmed: 23714062.

27. Zovein AC, Hofmann JJ, Lynch M, et al. Fate tracing reveals the endothelial origin of hematopoietic stem cells. Cell Stem Cell. 2008; 3(6): 625-636, doi: 10.1016/j. stem.2008.09.018, indexed in Pubmed: 19041779. 